\title{
How Teaching Styles Affect to Enhance Students' Mathematical Education
}

\author{
Dr. Karunanayake, Danesh. Ph.D. (Purdue)"1, Dilrukshi, M.C. BA (Hons), Psychology², \\ Vimukthi, N.D.U. BA (Hons), Psychology ${ }^{3}$ \\ Department of Psychology, University of Peradeniya, Sri Lanka
}

\begin{abstract}
Article Info

Volume 7, Issue 6

Page Number: 160-170

Publication Issue :

November-December-2020

\section{Article History}

Accepted : 10 Nov 2020

In the educational field, teaching styles are one of the most important aspects because student's knowledge, skills, and attitudes are dependent on it. Suitable teaching styles differ from subject to subject. Hence, we should find out the most suitable teaching styles for each subject. Mathematics is considered one of the most difficult subjects among students and it is a complex subject with practical applications. The main purpose of this research was to find out how teaching styles affect to enhance student's Mathematical education. The objectives of the study were to find out the most suitable teaching styles to teach mathematics and the advantages and disadvantages of each teaching style towards it. Under a qualitative research design, a semi-structured interview method with open-ended questions was used to collect data. The sample was six participants inclusive of both males and females from a rural provincial school in the Rathnapura district of Sri Lanka. The data were analyzed using thematic analysis. Results indicated that teaching styles directly influenced to enhance student's mathematical education. Further, it showed that every teaching style had advantages and disadvantages. Yet, the results could not confirm what the best teaching style for mathematical education is. The findings of the research will help spur further research to identify what the most suitable teaching style for mathematical education is and the positive and negative outcomes of each teaching style.
\end{abstract}

Published : 18 Nov 2020
Keywords : Teacher, Teaching Styles, Mathematical Education

\section{INTRODUCTION AND LITERATURE REVIEW}

Education is the most important discovery of human beings and it is the basic factor which counts for the development of our civilization. Also, it is the process of acquisition of knowledge, skill, beliefs, values, and habits. Therefore, education can be termed as a basic need for one's life. Education cures the different social evils and discrimination from society.

The teaching style is one of the most important factors in this field. Teaching styles also called 
teaching methods, are considered to be the general principles and management strategies for classroom instruction. The use of different teaching styles started at the beginning of the twentieth century. This was due to the amount of research being poured into different learning methods.

Teacher- A teacher is a provider of knowledge and insight, one who inspires, motivates, and opens up minds to the endless possibilities one can achieve, one who makes a positive difference in the lives of many, and one who is admired, appreciated, and held in the highest esteem (Urban dictionary, 2020; Karunanayake, 2000). A teacher is a person who instructs or trains others, especially in a school. (Dictionary.cambridge.org). According to Goldberg (2020), the teacher is greater than everything which is under the sun. Senadheera (2014) had given a similar definition for the teacher, "the meaning of teacher is the person who removes darkness and gives light". It means the person who can remove the delusions of students and gives the truth of life.

Teaching- "teaching is a scientific analysis" (Senadheera, 2014). Good teachers show students or help them discover for themselves, all sorts of things like what ideas are and how they can be used and the meanings of numbers and how to operate machines and on and on (Senadheera, 2014). The teacher shows ideas, concepts, and theories and finally teaches how to use them practically (Senadheera, 2014). Teachers are guided by certain principles of teaching and learning which have great implications for teaching. The role of the teacher is very essential in the effective implementation of the curriculum. Teaching challenges the 3 domains of learners namely cognitive, affective, and psychomotor. Teaching is a deliberate activity done professionally to bring a positive change to the learner (Dorgu, 2015). Teaching is an attempt to bring about desirable changes in human learning, abilities, and behaviors to contribute to better living.
It is also a means of passing knowledge to the next generation (Hammond, 2020).

Teaching style- Jayasena (1998) stated that it is a private action that is done by teachers for students. Also, he stated that the teaching method is a process to guide the learner in solving problems. All this information is included for the variable named "teaching style". The second variable is the enhancement of students' mathematical education. Here, the researcher tries to describe the conceptual background of education. According to John Stewart Mill, education means one generation giving things to the next generation for protecting their culture and joining something or modifying (West, 1965). In this, culture means the knowledge, beliefs, arts, customs, and skills of one generation. Weerasinghe (1999) stated that education is a practical use of philosophical theories to build human culture. Also, he tells that education is considered a transference of knowledge made from certain objectives and using correct teaching methods for students and society.

Everybody learns different ideas at different times and different places. Some people can learn something on the first try after being told what to do whereas others might need to have hands-on experience to learn and possibly repeat it a few times to get the hang of things. Different teaching styles are necessary because the students need to be able to learn what the teacher is teaching. Teaching styles are linked to a teacher's educational value system and stem from your philosophy of education. Being aware of your teaching style (or styles) can help you improve your teaching methods, and encourage more student engagement and, ultimately, student outcomes. It's the pattern of your teaching based on a set of strategies used within the classroom that you believe helps your students learn the material most effectively (Persaud, 2019). However, the choice of teaching styles used can also depend on the school 
mission statement, the classroom demographics, the educational philosophy of the teacher, and most importantly, the subject area. Hence, subject to subject the teaching styles should differ. Among subjects, mathematics is one of the most important subject areas and its contents differ from other subjects because it uses numbers and various calculations based on numbers. Mathematical education is referred to as the practice of teaching and learning of mathematics involving learning algorithms and formulas necessary for computations to solve problems (IGI Global, n.d)

According to most opinions of society, compared to other subjects, Mathematics is a complex and difficult subject. There are various reasons for such negative attitudes about the subject such as it is very difficult and that students don't like to work hard because they think that they can't understand Mathematics like other subjects. The teaching style is one of the most important factors which affect to enhance Mathematical education.

There are so many different studies about the relationship between teaching styles and student education. The following research study give a realistic picture and evidence of that. Effective teaching styles impact high levels of student engagement based on good classroom and time management skills, cognitively impact students in higher-order thinking, and encourage and support success. In this research about elementary classrooms, effective teaching skills are successful for all students, both with and without special education needs (Karunanayake, Madushani \& Vimukthi, 2020). They provided evidence that teachers' beliefs about disability and their responsibilities for their students with disabilities and special educational needs may be part of their main responsibilities. The implications for these findings are considerable for teacher training and development and teacher's effective teaching styles have a major impact to prepare a good classroom (Jordan, Christine \& Donna, 2009).

Hussain, \& Ayub (2012) researched the association between learning styles and teaching styles at the undergraduate level in a business school. There was a positive correlation between student learning style and teacher teaching style which was statistically significant. The results indicated that awarenessraising sessions should be arranged for students and teachers to realize the importance and implications of knowing their learning and teaching styles in the business education environment. Another study pointed out that the mathematical scores of students in classrooms with teachers using facilitator and delegator teaching styles were significantly higher than for students in classrooms of teachers using expert, formal authority, and personal model teaching styles. Students in classrooms with teachers with five or fewer years of teaching experience scored significantly lower marks than teachers with more than five years of teaching experience (Stanford, 2014).

According to past research, education and students' achievement is based on teaching styles and various characteristics and skills of the teacher. Every study has shown that teaching style, teacher's efficacy, motivation, support, and enthusiasm positively affect students' educational achievements. Further, past research has found that there is a positive relationship between a teacher's mathematical knowledge and a students' mathematical achievement. According to the above information, we can conclude that there is a relationship between a teacher's knowledge and style and a student's educational achievement. But, in the Sri Lankan context, it is difficult to find literature on the relationship between a teachers' teaching style and students' mathematical educational achievement. 


\section{METHODOLOGY}

The study used a qualitative research design utilizing semi-structured interviews with a list of open-ended questions based on the research topic area. The participants of the research were selected from grades 10 and 11 from a rural provincial school in the Rathnapura district. The sample was 6 students inclusive of 3 males and 3 females who volunteered to participate in the research. Thematic analysis was used to analyze data gathered from the semistructured interview. The semi-structured interview was held with the consent of the participants and the interviews were conducted with a pre-planned set of questions related to the research topic to capture the relevant information experiences of the participants. All six interviews were conducted on one on one basis. Although all six participants were interviewed using the same set of questions a great amount of flexibility was adopted and the participants were allowed to explain their opinions and ideas on the research topic freely. Participants were given an informed consent form including objectives, duration, and procedure of the research. Only volunteered participants were interviewed. Researchers ensured that participants were not physically or psychologically harmed; gave priority to participants' rights and welfare; respected participant's freedom to withdraw from the research at any time and ensured the confidentiality and security of the information gathered from the interview.

\section{RESULTS AND DISCUSSION}

The present study was conducted to identify the most suitable teaching styles to enhance students' Mathematical education. The results are described under themes and sub-themes. They are; Authoritarian teaching style (lecture style, limited freedom, punishment), Facilitator teaching style (giving resources, self-learning, freedom, and guidance), Programmed learning method (linear program learning, branched program learning, reinforcements), Demonstrator teaching style, Delegator style and Practical method (activities, learning with using material things). Male participants are identified as ' $M$ ' and female participants are identified as 'F'.

\section{Authoritarian teaching style}

This teaching style is based on three main qualities such as lecture focused, limited freedom, and punishments. According to the data collected no one likes to learn Mathematics as a lecture because of different reasons. Only clever students can understand the lesson well from a lecture, and it is difficult to understand the lesson for students who get less than 35 marks. When students learn mathematics as a lecture they feel sleepy and bored. Hence, they forget even the things which they can remember. The lecture method decreases the relationship between the teacher and the students because less attention is given to students. If it is a classroom with a large number of students it negatively affects students' performance in Mathematics. Finally, this method is not suitable for teaching mathematics because mathematics is a complex and practical based subject. M1- "When the teacher teaches as a lecture only students who are clever in Mathematics can understand the lesson. The students who score marks below 35 can't understand anything."

F2- "There are various subjects which we can listen to as a lecture. It is interesting to listen to Sinhala and history subjects as a lecture. But, when we listen to Mathematics as a lecture it is very boring and we feel sleepy. Then we forget even the things which we can normally remember."

Because a teacher is an expert person and his or her capacity is not similar to a students' capacities, 
although some students can understand the lecture method others can't. Therefore, students need to be given opportunities to find ways of learning that best suit their learning styles. Hence, limitation of freedom is not acceptable for Mathematics because freedom is necessary for students to find different ways to complete various calculations. There are different ways to get the same solution for a calculation. Hence, there should be opportunities to find new directions for students. Sometimes, students know easier techniques than teachers. Therefore, mathematics shouldn't be teacher-centered because the teacher should teach according to the student's knowledge, skills, and capacities. Also, teachercentered teaching decreases critical thinking, creativity, and intelligence.

M1- "In here even students who are clever for mathematics feel complicacy. When we use only one method we forget things which we know and it reduces the chances to use our knowledge."

F3- "It is not correct to teach according to only the teacher's knowledge because the teacher is considered an expert. It is most effective if the teacher can teach using easy methods which students like. It increases student's memory and understanding"

Students believe that punishments can bring both positive and negative outcomes for enhancing Mathematical knowledge. It is difficult to learn Mathematics with punishments because most of the students get fed up with teachers and it negatively affects their performances. Also, punishments sometimes affect their mental well-being negatively because when someone is punished in front of others they feel shy, helpless, and hopeless. But, sometimes it acts as positive reinforcement because it increases students' attention, gets them to do homework, and help increase their marks. Further, some students think that the teacher punishes to make their life better.

M1- "One can't use punishments to teach subjects like mathematics. It should be taught practically. Punishments happen only with teachers who are fed up."

F1- "I think it is ok if the teacher punishes when we don't do our homework. Punishments don't reduce our memory. Punishments always make us remember our mistakes. We are angry when we are punished. But I think the teacher punishes to make our life a success."

In conclusion, the authoritarian teaching style is not suitable for teaching Mathematics because it has more negative outcomes than positive outcomes for students' performances. It is a teacher-centered oneway method of teaching that excludes different learning styles of learners.

\section{Facilitator teaching style}

Three subthemes are described under this theme such as giving resources, self-learning, and freedom and guidance.

There are some specific tools for Mathematics that students should bring themselves. But, if some students can't bring them for a good reason such as lack of money then it is fair for teachers to give them resources. It gives a chance for the teacher to help students and students an opportunity to get help from teachers. Giving resources is more suitable for primary school classes than secondary school classes because of small class sizes and the willingness of primary school students to be involved. Also, secondary school students can better remember to bring from home things that the teacher tells them. 
F2- "Actually, it is good to be like this teacher. Some students can't bring tools that are needed for a lesson because of a lack of money. From this teaching style, teachers get a chance to help these students and students can get help from a teacher."

F3- "If the reason students don't bring things which they need is fair then the teacher gives tools. Some teachers punish without asking the reason. It is unfair for poor students."

Freedom is the most important subtheme of the facilitator teaching style and it encourages selflearning which is student-centered. It is not suitable to allow students to solve calculations without any teaching because students can't calculate new calculations alone. It is good if the teacher gives new calculations after giving some examples. Self- learning guides students to think critically and find new ways to do calculations. It gives students a chance to understand their capacities, skills, and knowledge by themselves. But this method is useful for only clever students because they can try to solve calculations by themselves whereas other students may feel helpless. Hence, this method is valuable for clever students to establish self- understanding and to recognize for themselves both positive and negative outcomes.

M1- "Before giving questions all at once the teacher should first show the way with two or three examples. After that, it is suitable to give freedom to students to find the solutions. It is difficult to calculate new questions all at once. So, I don't like this style.”

F3- "This method is suitable for students who aim for high marks. Normally, it is difficult for students who get less than 50 marks. Students feel helpless when the teacher gives questions without teaching."

Students, especially the clever ones, see both freedom and guidance from self-learning as decreasing negative outcomes because both freedom and guidance helps them to bring out the best performances for Mathematics subject.

F1- "If the teacher gives questions without guidance students may calculate wrongly. So, the teacher shouldn't give only freedom. Students calculate from different methods. Then various problems will be solved. The teacher should be near the student and look at calculations that students perform whether they are right or wrong."

F2- "If there is proper guidance, a good relationship and co-operation are built between student and teacher. Then, the student is motivated to work hard." Without guidance, students can't learn because they face many problems while they are doing calculations. Further, this method can build a good relationship between teacher and student because cooperation and communication are higher than in other methods.

\section{Programmed learning method}

There are three subthemes of programmed learning method; linear program learning, branched program learning, and reinforcements.

Linear program learning means teaching lessons step by step. There are various calculations that students can't understand all at once. Hence, step by step learning is a more effective teaching method to understand the full lesson well. Also, students see that their marks increase from this method. Attention and motivation can be increased by linear program learning than other teaching methods. It can help every student irrespective of the level that they are in. However, students who are weak at Mathematics can get lots of advantages from this method than clever students. Further, it is the most valuable method to learn long calculations because students can't understand those lessons all at once. If they learn 
long lessons step by step it is effective in increasing their performances and memory.

F1- "There are so many different calculations. There are some calculations that we can understand easily and others that we can't understand however much we tried. So, this method is good for breaking down the calculations which we can't understand easily."

M2- "This year, we have got this teacher to teach mathematics. Her method is really good. It helps us understand very well. So, students are motivated to learn well compared to before. I also like mathematics more after starting to learn from this method. I see that as well as their interest the marks of students have increased."

Branched program learning is not suitable for a traditional teacher. The success of this method is decided according to the creativity and practical thinking of the teacher. The teacher needs to select different methods to teach various lessons focusing on students' needs and knowledge levels until students understand the lesson. Some teachers don't pay attention to the incompetent students. Hence, those students try to miss the Mathematics period. A teacher who tries to pay attention to everyone receives love and trust from all students. It can increase students' motivation and get them to work hard.

F2- "This is decided according to the skills of the teacher. The reason is a teacher should have the skill which to be practical and creative. The teacher must explain the lesson using different methods which are suitable for each student. This method is never done by teachers who are traditional and don't think about students."

M1- "I felt a feeling of helplessness when I couldn't make calculations. That teacher taught only clever students. He never found out weak students. So, we had a period in which we were fed up of Mathematics."

Reinforcement is the process of encouraging or establishing a belief or pattern of behavior. The term reinforce means to strengthen and is used in psychology to refer to any stimulus which strengthens or increases the probability of a specific response.

M1- "when the teacher gives rewards and praises, students are motivated to work hard. In our childhood, there were lots of things like those because small children like them so much. Now, students who get the highest marks are given free cards in our classes. Hence, there is a big competition between us."

F2- "We are interested to listen to the lesson because of this. Even the student who doesn't like Mathematics feels interested in Mathematics. Then student's knowledge increases and they feel interested to learn. This is the best method to motivate students."

In this study, the researcher found that teachers use positive reinforcements like rewards and praises. Every student likes to be admired in front of others because it brings pride and honor to themselves. In the current education system in Sri Lanka, teachers use different reinforcements like free cards in tuition classes.

\section{Demonstrator teaching style}

This style is not traditional and is based on new technology like multimedia presentations, activities, and demonstrations. These things are very useful for practical subjects such as science and mathematics. This method brings a positive mental and physical change for students because it differs from other teaching styles. 
F2- "The amount of remembering is high because this method is not regular. When you tube videos about theorems, orders, and short methods in mathematics are shown it can increase student's attraction to mathematics."

M3- "This method is very good. All our subjects are taught traditionally. Hence, I think that students should get benefits from the present technology. I think if we can use technology in subjects like Mathematics it will positively affect students. Technology can remove the dislike of Mathematics which students' have because students now live with technology."

Although urban schools always get technological facilities, rural schools get fewer opportunities. Most teachers don't use this method even when they have facilities. Hence, when students get this chance they are motivated to get full advantages of it. The most important negative outcome of this method is that students' attention going to technology than the lesson. It also reduces the relationship between the teacher and the student but to learn Mathematics well there should be a good relationship between the two. So, to reduce these negative aspects teachers can discuss with students about the things which are presented with multimedia. Most students think that this method can be used positively if teachers can show small videos about theorems, orders, and short methods. Then, students are motivated to understand lessons better than traditional teaching methods. Finally, it may remove a student's dislike for Mathematics.

\section{Delegator teaching style}

The delegator teaching style is teaching by getting students into groups. This method can improve communication and cooperation between students since every student gets a chance to associate with their classmates in their group. Therefore, they get to identify with each other well. Students can also share their knowledge with group members and this will help increase the knowledge of incompetent students. M2- "We can do calculations using all ideas. When the teacher gives a geometry question we can solve it from not only one method but from various methods. If there are five members we may have five different methods to solve it. Hence, we may get to know new methods, short and easy methods, sometimes we can know better methods than the teacher's method."

M1- "When calculations are given as a group activity, some students try to escape from doing their share. They spend time purposelessly. The students who do work do their job thoroughly. The students who don't do work just chat."

F3- "With group method, students can get help for calculations from clever students. When they explain the calculations their memory is also increased. We don't feel lazy because we can discuss with friends and work."

Students know different ways to solve calculations and can share their ideas. Sometimes it may help to increase their knowledge more than in mere teaching. Also, students don't feel lazy and sleepy because they do calculations while engaging in discussions. Further, most of the students can understand the lesson quickly than from a teacher's teaching because the level of knowledge is similar between friends. Discussing and teaching others improves a student's memory and critical thinking. But, sometimes this method is negative because students are motivated to discuss unnecessary and unrelated things with group members. Yet, if the teacher can keep a watchful eye on the groups these negative outcomes can be reduced. 


\section{Practical method}

The practical method has two sub-themes; activities and learning with materials. Many activities can improve students' creativity, critical thinking, cooperation, and communication skills. This method is useful for Mathematics because Mathematics is a very practical and complex subject. Activities allow students to see the same issue from different perspectives. Thereafter, other students are also motivated to see issues from different perspectives. Activities also enable students a chance to share their knowledge. Most importantly it can remove a student's laziness and reduces the complexity of Mathematics subject. Hence, teachers can arrange activities with students to enhance their mathematical education.

F1- "This method is the best method to increase cooperation between students. Then, students think creatively and start to look at calculations from various perspectives. Also, it increases our critical thinking."

F2- "We don't feel lazy when we learn with different activities. Mathematics is a difficult subject for us. That dislike can be removed from this method. We don't feel the time passing. Hence, mathematics must be taught practically."

Learning with materials is also ideal for mathematics because there are specific tools that should be used in mathematics. Primary school teachers always use materials for teaching because tactile learning is effective to increase memory. First, the teacher should teach how to use the materials correctly by demonstrating in front of the students.

M3- "It is useless to learn lessons like shapes from a lecture. We should use tools and draw with the teacher ourselves. Unless we draw we can never create shapes by ourselves. So, I like this method."

F1- "Mathematics is a subject which we have to learn from using various things. From this method, we get a chance to share tools and collaborate with friends. Because we learn with various activities we don't feel sleepy."

This method also gives students a chance to share tools with friends thereby increasing their cooperation. On the downside, learning with materials may lead to wasting time, and because schools give limited time to learn mathematics both teachers and students have a responsibility to manage their time efficiently and effectively.

\section{CONCLUSION}

The result showed that teaching styles influence student's Mathematical education and that it affects students differently. There were both advantages and disadvantages to every teaching style. Teaching styles have affected students' motivation, results, and attending to Mathematics classes regularly. It is difficult to state one teaching style as the best one for enhancing students' mathematical education.

Students have both negative and positive attitudes about each teaching style. A lot of students have a negative perception of the authoritarian teaching style although some students saw it as a positive reinforcement. Most of the students like to learn Mathematics practically with materials than from a lecture. All students want both freedom and guidance from the teachers to understand the lesson well. They like teachers who teach lessons step by step and who use the group method. Students admired the teacher's affection, cooperation, attention, and communication as the best things to motivate them. 


\section{REFERENCES}

[1]. Urban dictionary (2020). Definition for teacher. Retrieved from: https://www.urbandictionary.com/define.php?t erm=teacher

[2]. Karunanayake, D. (2000). A comparison of role model influence between Caucasian and Minority College students in making academic and career decisions. Unpublished Masters'thesis, Illnois State University, Normal, IL, USA

[3]. Dictionary.cambridge.org, (n.d). Definition of teacher. Retrieved from: https://dictionary.cambridge.org/dictionary/eng lish/teacher doi:https://doi.org/10.1016

[4]. Goldberg, E. (2020). What is like to be a teacher in 2020, America. Retrieved from: https://www.nytimes.com/2020/10/05/us/teache rs-covid-schools-pandemic.html

[5]. Senadheera, S. (2014). Guru karyakshamatha sanwardhanaya. Colombo 10. S Godage saha sahodarayo.

[6]. Dorgu, T.E. (2015). Different Teaching Methods: A Panacea for Effective Curriculum Implementation in the Classroom. International Journal of Secondary Education, 3, 6-1, , pp. 7787. Retrieved from doi: 10.11648/j.ijsedu.s.2015030601.13

[7]. Jayasena, Ashoka. (1998). Praveena wruthikayeku weema sandaha igenveeme karma. Gothatuwa Nawa nagaraya. Siri Ranjana Prakashana

[8]. West, E.G. (1965). Liberty and Education: John Stuart Mill's Dilemma. Liberty, the Journal of the Royal Institute of Philosophy, April 1965. Retrieved from: https://egwestcentre.files.wordpress.com/2012/0 7/liberty-and-education.pdf
[9]. Weerasinghe, H. (1999), Adyapana sankalpa peradiga ha aparadiga. Colombo 10. S. Godage saha sahodarayo.

[10]. Persaud, C. (2019). Teaching styles: the ultimate guide. Retrieved from: https://tophat.com/blog/teaching-styles

[11]. IGI Global, (n.d). What is mathematics education? Retrieved from: https://www.igiglobal.com/dictionary/mathematicseducation/18030

[12]. Karunanayake, D., Madushani, K, Vimukthi, N.D.U. (2020).The importance of identifying students with learning difficulty in the school context. Asian Journal of Education and Social Studies. AJESS, 12(3), 2020

[13]. Jordan, Anne \& Glenn, Christine \& McGhieRichmond, Donna. (2010). The Supporting Effective Teaching (SET) project: The relationship of inclusive teaching practices to teachers' beliefs about disability and ability, and about their roles as teachers. Teaching and Teacher Education - TEACH TEACH EDUC. 26. 259-266. 10.1016/j.tate.2009.03.005.

[14]. Hussain, N. \& Ayub, N. (2012). Learning Styles of Students and Teaching Styles of Teachers in Business Education: A Case Study of Pakistan. Procedia - Social and Behavioral Sciences. 69. 10.1016/j.sbspro.2012.12.122.

[15]. Stanford, A. G. (2014, June). The effects of teachers' teaching styles and experience on elementary students' Mathematical achievement. Retrieved from https://digitalcommons.liberty.edu 


\section{Cite this article as :}

Dr. Karunanayake Danesh, Dilrukshi M. C., Vimukthi N. D. U., "How Teaching Styles Affect to Enhance Students' Mathematical Education", International Journal of Scientific Research in Science and Technology (IJSRST), Online ISSN : 2395-602X, Print ISSN : 2395-6011, Volume 7 Issue 6, pp. 160-170, November-December 2020. Available at doi : https://doi.org/10.32628/IJSRST207616

Journal URL : http://ijsrst.com/IJSRST207616 